\title{
A Set of Roman Belt Fittings. A BENEFICIARIUS LEGATI LEGIONIS III CYRENAICAE?
}

\section{REZUMAT: UN SET DE ACCESORII DE CENTURĂ ROMANĂ. UN BENEFICIARIUS LEGATI LEGIONIS III CYRENAICAE?}

În această lucrare prezentăm câteva obiecte de bronz din secolul al III-lea d.Hr., inclusiv accesorii pentru centură militară și o placă care împodobea o cutie sau un sicriu. Proveniența obiectelor este necunoscută. Importanța publicării lor provine din menționarea rară a numelui unei legiuni romane, juxtapunerea faptelor relevante pentru datarea lor cu contextul geografic și lipsa analogiilor cunoscute. Analizând datele, putem sugera cu prudență că obiectele provin dintr-un mormânt din nordul Cisiordaniei sau din sudul Siriei care aparținea unui beneficiarius din Legiunea III Cyrenaica staţionată în provincia Arabia în perioada romană târzie.

\begin{abstract}
:
In this paper we present bronze objects from the third century CE, including military belt fittings and a plate that adorned a box or coffin. The provenance of the objects is unknown. The importance of publishing them stems from the rare mention of the name of a Roman legion, the juxtaposition of facts relevant to their dating with the geographical context, and the paucity of similar known exemplars. Having analyzed the data, we can cautiously suggest that the objects come from a tomb in northern Transjordan or southern Syria that belonged to a soldier perhaps a beneficiarius - in the Legio III Cyrenaica stationed in the province of Arabia during the Late Roman period.
\end{abstract}

CUVINTE CHEIE: Arabia, Legio III Cyrenaica, Late Roman period, beneficiarius, belt fittings.

KEYWORDS: Arabia, Legio III Cyrenaica, Late Roman period, beneficiarius, belt fittings.

\section{Introduction}

In this paper we present an assemblage of bronze objects from the Late Roman period, including military belt fittings and a plate that adorned a wooden box or coffin. Because the provenance of the objects is unknown, we have to be cautious about drawing historical conclusions from them. Nevertheless, the juxtaposition of facts relevant to their dating with the geographical context (which enables us to cautiously trace the origin of the objects) and the paucity of Roman belt fittings of known provenance increase the importance of the present discussion. First we will describe the items and then we will discuss their dating and use, while attempting to trace their origin and considering their functional and historical-cultural context. 

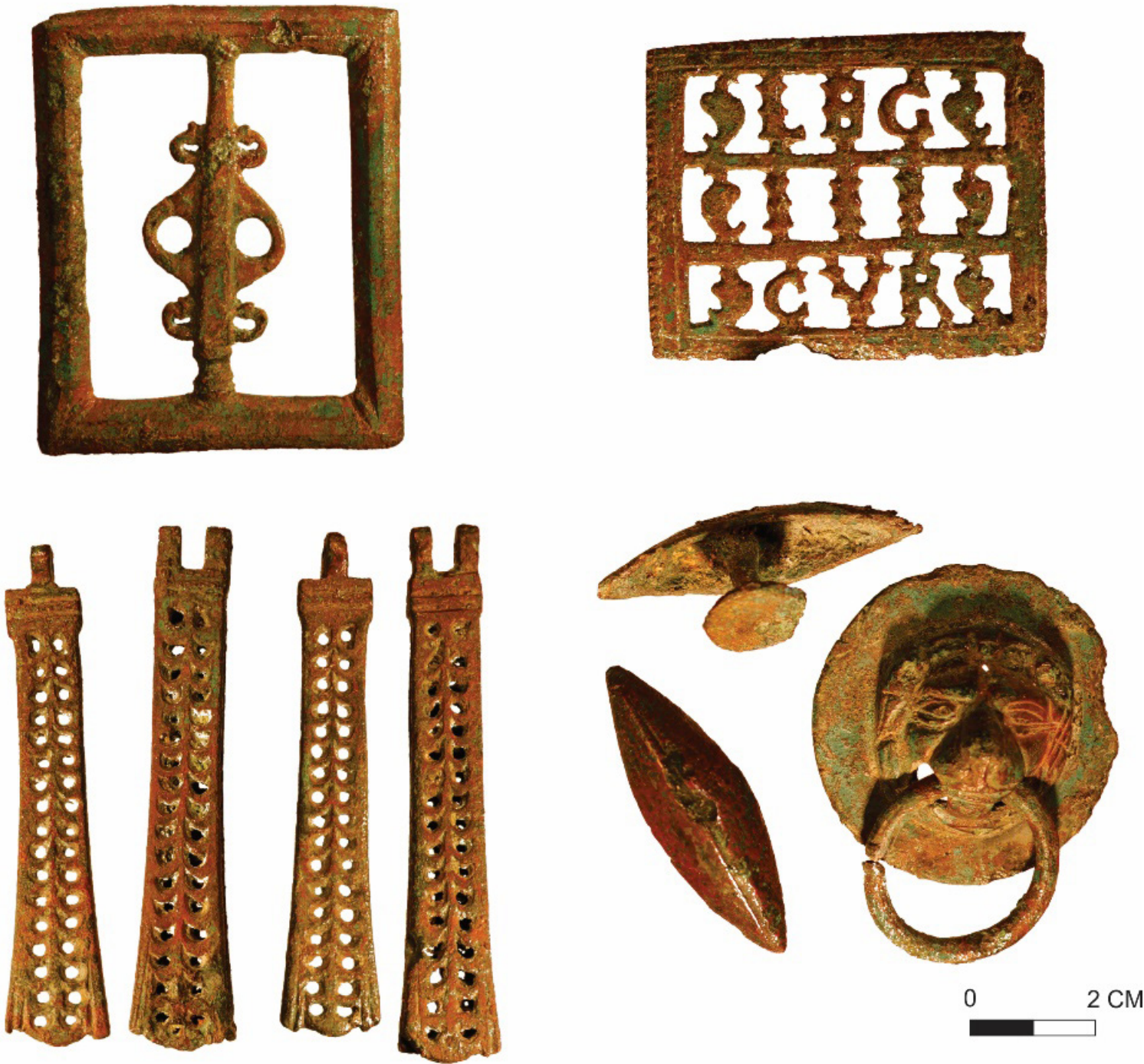

\section{Description of Artifacts}

\section{Buckle (Pl. I.1)}

Description: A rectangular, double-loop frame buckle.

One end of the belt passed through each loop. The middle section is decorated in openwork with a beneficiarius lance symbol.

Dimensions: $56 \mathrm{~mm}$ wide; $69 \mathrm{~mm}$ long. Based on the inner dimensions, the width of the belt was less than $52 \mathrm{~mm}$.

Date: Rectangular frame buckles were common during the third century CE.

Parallels: Hoss 2014, Tables 22-23: A.839-887, especially Table 23: A.882. See also

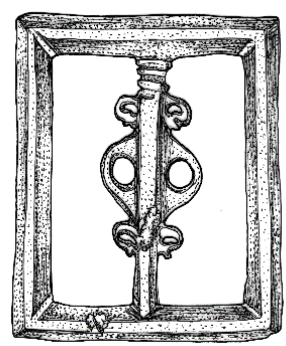
Hoss 2012, 39, fig. 4.5.

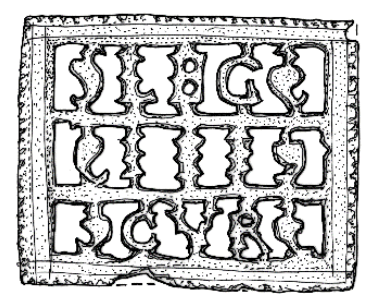

\section{Belt Plate (PI. I.2)}

Description: A rectangular belt plate decorated with the abbreviated Latin name of the legion, executed in openwork: LEG III CYR (i.e., Legio III Cyrenaica). Schematic ivy leaves fill the spaces between the letters and the frame, adding structural strength. The plate was attached to the belt with four rivets on its reverse. Dimensions: $50 \mathrm{~mm}$ wide; $61 \mathrm{~mm}$ long. Based on the direction of the inscription, the width of the belt was no less than $50 \mathrm{~mm}$. 
Date: Letter-shaped mounts spelling out words were popular during the late second to mid-third centuries CE.

Parallels: - For the form of the inscription, see Hoss 2014, Table 46:B.1009-1017.

- For the letters LEG CYR on a belt, see Fischer 2012, 127.

\section{Studs (PI. II.3-4)}

Description: Two lenticular fungiform studs sewn on the waist belt or baldric at the portion between the buckle and the end of belt. They were probably used to reinforce the buckle lock. Each stud has pins for attachment to leather and were probably placed vertically on a wider belt.

Dimensions: Each stud is $50 \mathrm{~mm}$ long, $16 \mathrm{~mm}$ wide, and $21 \mathrm{~mm}$ high.

Date: Third century CE.

Parallels: Hoss 2014, Tables 75-76:G.81-91.



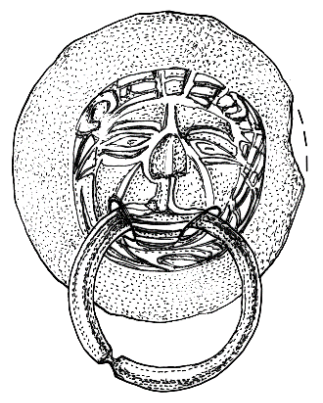

\section{Strap Terminals (PI. III)}

Description: Two pairs of strap terminals of similar shape: Each consists of two parts: one part with double straps and the other with one strap. Each strap has 17 pairs of eyes in openwork.

These items were used as hinges for adjusting the freely hanging strap end of a belt, which was split in two ends. One part of it hung from the belt and the other could be used to pull down the belt, but their main function was decorative.

Dimensions: Each piece is $81-84 \mathrm{~mm}$ long and $1.1-1.6 \mathrm{~mm}$ wide.

Date: Third century CE.

Parallels: Hoss 2014, Tables 84-85:H.424-432; James 2004, 83-84, fig. 39:136.



\section{Discussion}

The provenance of the items under discussion is unknown. As we shall see, some of the data suggest that they come from a tomb in northern Transjordan or southern Syria. They were purchased together before proper cleaning and conservation and were clearly covered by a similar patina ${ }^{1}$. A look at parallels indicates that the objects belong to a Roman military belt kit, except for one item that adorned a wooden box or coffin. The similar patina and good state of preservation of the assemblage suggest that the objects were discovered together, apparently in a tomb. The assumption that the items were found together is supported by the dating and the cultural and geographical context (see below). The items are made of a copper alloy covered with green corrosion and are in a relatively good state of preservation; in contrast, the belt and box to which they were once attached were made of perishable materials - leather and wood, respectively_which have not survived.

Based on the shape of the items (especially the square shape of the buckle and belt plate), the shape and dimensions of the fastenings, which would suit a fairly wide belt (about $50 \mathrm{~mm}$ ), and a comparison with dated parallels, we can identify them as belonging to a military belt from the third century $\mathrm{CE}^{2}$. This dating is supported by the lion head plate, which belongs to a known type of Roman coffin decoration from that period (see below).

\footnotetext{
The objects are currently in the collection of Dr. David and Jemima Jeselsohn, Zurich. We are grateful to Dr. Jeselsohn for showing them to us and encouraging us to publish them and to Dr. Renate Rosenthal-Heginbottom, Dr. Ovidiu Ţentea, Dr. Alexandru Raţiu and Dr. Avner Ecker for their useful remarks.

2 On military belts from this period, see Bishop and Coulston 2006, 154-163, 182-184; Hoss 2014, 262-284.
} 
The belt-buckle is decorated with the symbol of a beneficiarius legati legionis, the insignia that in itself it is a remarkable discovery. The bearear of this insignia, along with the inscription on the belt plate could have been no less than a beneficiarius legati legionis, a soldier entrusted with a special assignment from the legate ${ }^{3}$.

The belt plate, which bears the Latin inscription "LEG III CYR" (i.e., Legio III Cyrenaica), is especially noteworthy. Inscriptions on Roman belt fittings are fairly rare ${ }^{4}$, and rarer still are inscriptions mentioning a particular legion ${ }^{5}$, At present we know of one other Roman belt with the inscription "LEG III CYR"; its source is apparently Israel and it is currently in a private collection in England ${ }^{6}$, Our inscription indicates that the belt assemblage belonged to an officer in this legion; the material of which the items were made - bronze rather than silver - may be indicative of a relatively junior rank ${ }^{7}$.

Based on drawings of legionnaires from the third century CE (e.g., the fresco from Dura-Europos featuring the tribune Terentius in a cultic scene and depictions on tombstones and altars), we can reconstruct the location of the items in question along the waist belt (balteus), although it is possible that some of them hung from the shoulder belt (baldric). Shoulder belts first appeared in the second century CE in addition to waist belts and were designed to hold the spatha sword, which is longer than its predecessor, the gladius.

The lion head plate included in the set resembles either a device on which to hang objects or a phalera (a decorative disk in the military dress kit) ${ }^{8}$. However, the absence of an attachment ring on the back of the plate typical of these devices, the ring in the lion's mouth, and especially the similarity to a group of objects classified by Weber (1989) as Roman coffin decorations characteristic of Syria attest that this is a fitting from a Syrian wooden box or coffin. These items are generally made of bronze (with the exception of one silver specimen) and are found in sets consisting of one or more pairs of items. They are fastened to the wooden wall by means of short nails hammered into the back of a plate. Because wooden coffins do not survive long, none decorated with plates have been found, and their location on the coffin was reconstructed based on depictions of similar items on stone sarcophagi'. The lion head with a ring in its mouth is a common decoration on Late Roman-period sarcophagi. Apparently, lion heads and lions in various contexts were placed on sarcophagi due to the symbolism attributed to these powerful beasts in antiquity. Lions represent the destructive force of death but also powerful forces that can guard against death, to the point that an apotropaic function was ascribed to the lion; hence the significance of its appearance in a funerary context ${ }^{10}$.

The relatively modest dimensions of our lion head plate (diameter of $5 \mathrm{~cm}$ ), compared to most known plates (9-22 $\mathrm{cm}$ ), are noteworthy and suggest that it adorned a wooden box. Naturally, few such boxes have survived from the Roman world. A particularly impressive strongbox was discovered in Villa B (also known as the Villa of Lucius Crassus Tertius) in Oplontis, in the Bay of Naples, a site destroyed by the eruption of Vesuvius in 79 CE. The strongbox was an ornate, iron-plated wooden box (arca) inlaid with silver and bronze and having a sophisticated locking mechanism. Jutting out in front is a handle in the form of a bronze plate adorned with the head of a lion carrying a ring in its mouth ${ }^{11}$.

The object in our assemblage adorned with a lion head can help us identify the provenance of the assemblage. First, it reinforces the possibility that the items were discovered in a tomb, because the vast majority of known lion head plates adorn coffins. Second, many similar items originate from Syria. In his basic study, which includes a typological, chronological, and geographical distribution, Weber divided these items into six geographical groups distinguished by their production techniques and style. Our object belongs to the southwestern group, which is characterized by a lion depicted schematically ${ }^{12}$. The items in this group were found at a series of sites in

\footnotetext{
On beneficiarii, see Ott 1995; Nelis-Clément 2000; On a funerary inscription of a beneficiarius legati legionis III Cyrenaicae from Bostra [D(is) M(anibus) / L(ucius) Cassius / Longinu(s) / benefic(iarius) / leg(ati) leg(ionis) / III Cyr(enaicae)], see: Jalabert et Mouterde 1929: 13, 1, 9176; Schallmayer et al. 1990: 724; Ott 1995, 71-72 Epigraphik-Datenbank Clauss / Slaby, no. 11301185 (https://db.edcs.eu/epigr/epi ergebnis.php).

4 A common inscription on Roman military belts (both on the belt plate and on phalerae on the baldric) is the motto "Utere Felix" ("use with good fortune"), which usually appears as separate letters. See Hoss 2017, 100, fig. 5.3 and discussion on pp. 104-105.

5 See, e.g., Meshorer 1984, 41-43.

6 Fischer 2012, 127

James 2004, 258.

8 Devices on which to hang objects were relatively common in the third century CE and sometimes include a ring (see, e.g., a belt set from Dura-Europos in which a strap terminal similar to the one discussed here has a hanging device that includes a ring [James 2004, 53]).

9 Weber 1989, Tables 61:3-4, 62 .

10 Huskinson 2015, 188-190.

11 Muslin 2016, 166-170.

12 Weber 1989, 39-42. There are two noteworthy differences, however: (1) the modest dimensions of our object compared to
} 
northern Transjordan and on the Golan Heights (Tafas, Tell al-Ashari, Um Qeis-Gadara, and Tell Um Hauran). This region is relatively close $(30-40 \mathrm{~km})$ to Bostra, the capital of the province of Arabia, which served as a base and headquarters for the Legio III Cyrenaica in the second through fourth centuries CE ${ }^{13}$. It is worth noting that some lion head plates found at Bostra itself and in the vicinity (the region of Hauran, in southern Syria) belong to the southern group; one such item belongs to the northern group. In any case, the similarity to the southwestern group and mention of the Third Legion on one of our belt fittings, dated to the third century CE, allow us to assume that the items come from a tomb in the Bostra area or a nearby military site where troops from the Legio III Cyrenaica were stationed. This assumption is supported by the widespread practice of burying legionnaires in the area where they served or were killed ${ }^{14}$. There had to have been army bases in southern Syria and northern Transjordan for troops from the Third Legion given the role of this legion in defending the southeastern border of the Roman Empire ${ }^{15}$. The existence of these bases is indicated, inter alia, by inscriptions discovered throughout the province that mention officers from the Legio III Cyrenaica — at Petra ${ }^{16}$; Wadi Sirhan, east of Jawf ${ }^{17}$; and perhaps even Nemara ${ }^{18}$.

Our assemblage can be added to dozens of other examples, most of them from the Late Roman period, of burial with military equipment, a practice believed to have been relatively rare in the Roman Empire ${ }^{19}$. Another manifestation of this practice is the depiction on gravestones of uniformed legionnaires carrying military equipment. Presumably it was mainly done when the soldier buried and memorialized fell in the course of his military service.

\section{BiBLIOGRAPHY}

Bennett, C.M. and Kennedy, D.L. 1978. A new Roman military inscription from Petra. Levant 10: 163-165.

Bishop, M.C. and Coulston, J.C.N. 2006. Roman Military Equipment: From the Punic Wars to the Fall of Rome. Oxford: Oxbow (2nd edition).

Bowersock, G.W. 1983. Roman Arabia. Cambridge: Harvard University Press.

Broulet, R. 1984. Estampiles de la IIIe légion Cyrénaique à Bostra. Berytus 32: 175-179.

Butcher, K. 2003. Roman Syria and the Near East. London: British Museum.

Carrol, M. 2006. Spirits of the Dead: Roman Funerary Commemoration in Western Europe. Oxford: Oxford University Press.

Castro, M. 2018. The Function of the Roman Army in Southern Arabia Petraea (Archaeopress Roman Archaeology 48). Oxford: Archaeopress.

Fischer, T. 2012. Die Armee der Caesaren: Archäologie und Geschichte. Regensburg: Friedrich Pustet.

Hollard, D. 2004. Le monnayage de la Legio III Cyrenaica frappé à Bostra sous Antonin le Pieux. Revue Numismatique 6(160): 155-173.

Hope, V.M. 2009. Roman Death: The Dying and the Dead in Ancient Rome. London: Continuum.

Hoss, S. 2012. The Roman Military Belt. in: M.-L. Nosch (ed.), Wearing the Cloak: Dressing the Soldier in Roman Times. Oxford: Oxbow Books: 29-44.

Hoss, S. 2014. Cingulum militare: Studien zum römischen Soldatengürtel des 1. bis 3. Jh. n. Chr. Unpublished $\mathrm{PhD}$ dissertation, Leiden University.

those in the group; (2) the absence of rings in the lions' mouths on the objects in the group.

13 The relocation of the legion to this region is believed to have been carried out for military and economic purposes (Castro 2018, 38). The legion was stationed at Bostra (Bosra), the provincial capital, which became its main base and headquarters for the next three centuries (Gatier 2000). For the inscriptions of the Legio III Cyrenaica from Bostra, see Youtie and Winter 1951, no. 466, 1.48; Sartre and Sartre-Fauriat 2011. On the coinage, see Kindler 1983, 87-95; Hollard 2004. On the stamps, see Broulet 1984, 175-179. A large rectangular enclosure on the northern side of Bostra has been identified as the camp of the Legio III Cyrenaica (Butcher 2003, 418).

14 Carrol 2006, 156-168, 186-188, 211-232; Hope 2007, 155-156.

Parker 1928, 9; Castro 2018, 19-20.

Bennett and Kennedy 1978.

Bowersock 1983, 118.

Bennett and Kennedy 1978, 165.

9 Bishop and Coulston 2006, 33. 
Hoss, S. 2017. The Roman Military Belt - a Status Symbol and Object of Fashion, in: T.F. Martin and R. Weech, (eds.). Dress and Society. Contributions from Archaeology. Oxford: Oxbow Books: 94-113.

Huskinson, J. 2015. Roman Strigillated Sarcophagi: Art and Social History. Oxford and New York: Oxford University Press.

Jalabert, L. et Mouterde, R. 1929. Inscriptions grecques et latines de la Syrie. Paris: Geuthner.

James, S. 2004. The Excavations at Dura-Europos Conducted by Yale University and the French Academy of Inscriptions and Letters 1928 to 1937, Final Report VII: The Arms and Armour and Other Military Equipment. London: British Museum.

Kindler, A. 1983. The Coinage of Bostra. Warminster: Aris and Phillips.

Meshorer, Y. 1984. Two finds from the $10^{\text {th }}$ Roman Legion. Israel Museum Journal 3: 41-45.

Muslin, J.L. 2016. Working and living in Oplontis B: material perspectives on trade and consumption, in: E.K. Gazda and J.R. Clarke (eds.) Leisure and luxury in the age of Nero: the villas of Oplontis near Pompeii (Kelsey Museum publication 14): 165-170. Ann Arbor: Kelsey Museum of Archaeology.

Nelis-Clément, J. 2000. Les beneficiarii. Militaires et administrateurs au service de l'Empire (Ier s. a.C. - VIe s. p.C.) (Ausonius publications. Études 5). Paris: Boccard.

Ott, J. 1995. Die Beneficiarier. Untersuchungen zu ihrer Stellung innerhalb der Rangordnung des Römischen Heeres und zu ihrer Funktion. (Historia Einzelschriften. Heft 92); Stuttgart: Franz Steiner Verlag.

Parker, H.M.D. 1928. The Roman Legions. Oxford: Clarendon.

Sartre, M. and Sartre-Fauriat, A. 2011. Bostra et la Plaine de la Nuqrah. Vol. 13(2) of Inscriptions Grecques et Latines de la Syrie. Beirut: Institut français du Proche-Orient.

Schallmayer, E., Eibl, K., Ott, J., Preuss G., und Wittkopf, E., 1990. Der römische Weihebezirk von Osterburken I: Corpus der griechischen und lateinischen Beneficiarier-Inschriften des Römischen Reiches, Stuttgart: Theiss.

Weber, T. 1989. Syrisch-römische Sarkophagbeschläge: Orientalische Bronzewerkstätten in römischer Zeit. Mainz am Rhein: P. von Zabern.

Youtie, H.C. and Winter, J.G., eds. 1951. Papyri and Ostraca from Karanis, 2nd series (Michigan Papyri 8). Ann Arbor: University of Michigan Press.

DVIR RAVIV

Bar-Ilan University, Israel

Ravivd2@biu.ac.il

BOAZ ZISSU

Bar-Ilan University, Israel boaz.zissu@biu.ac.il 

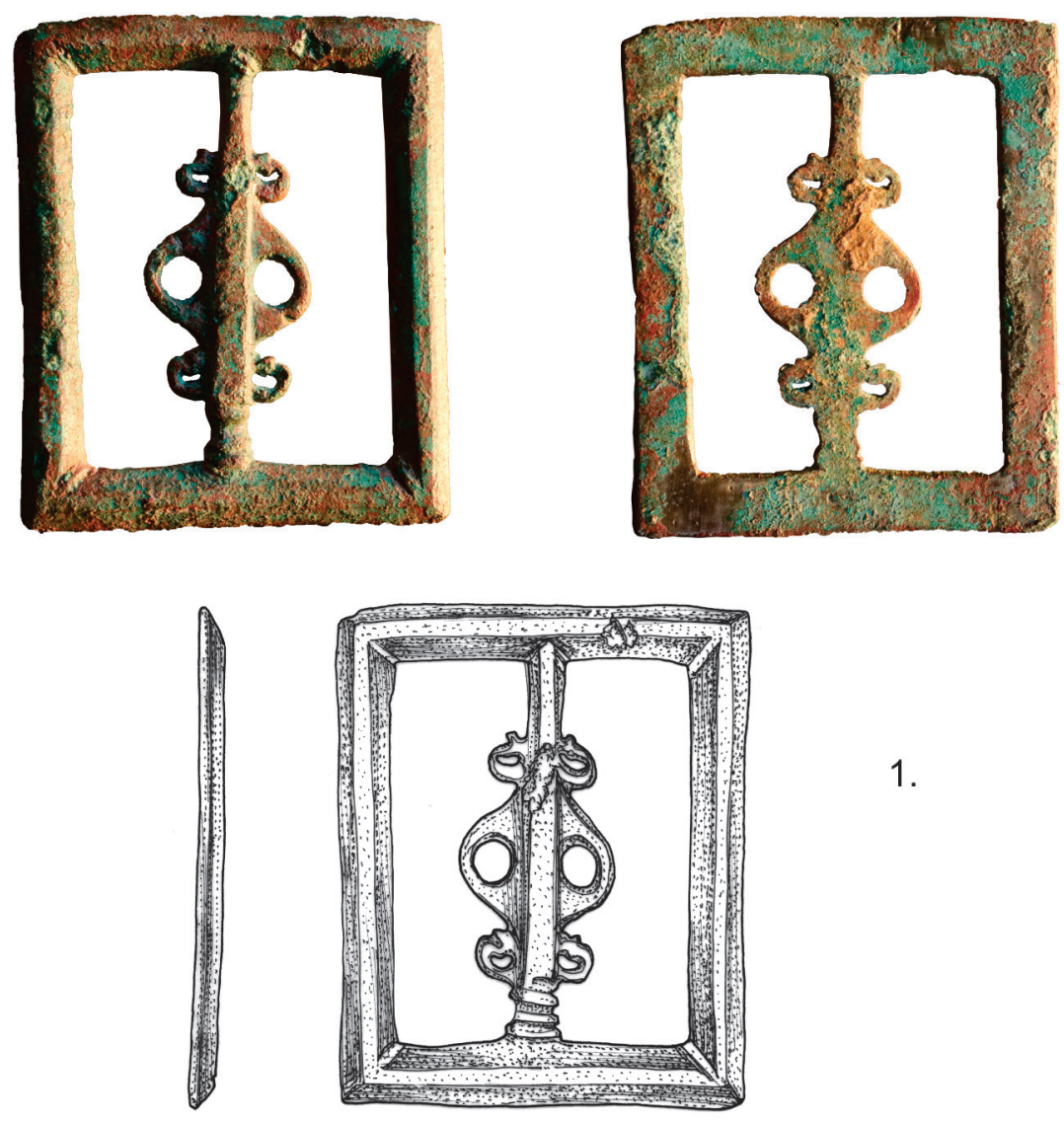

1.
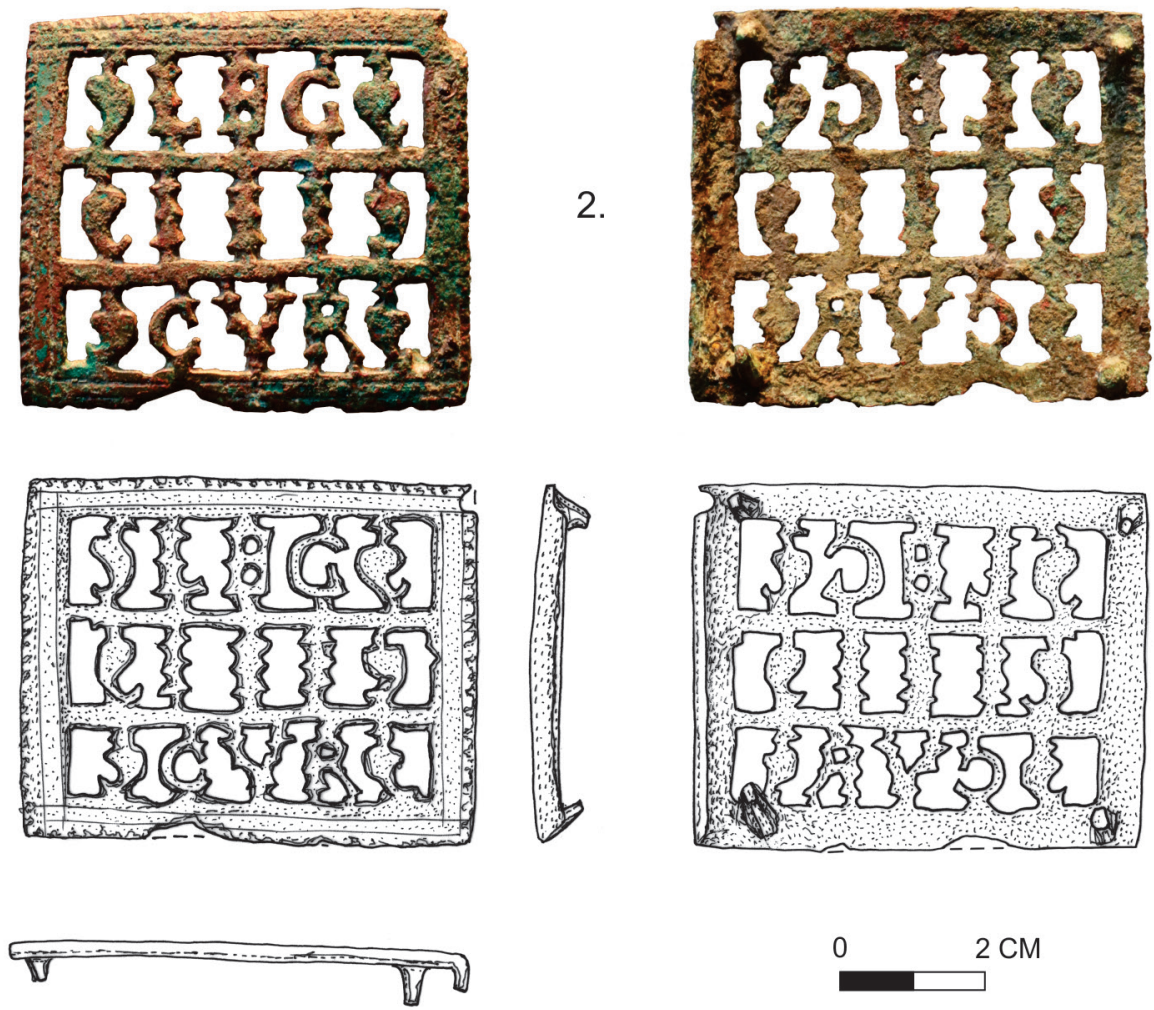

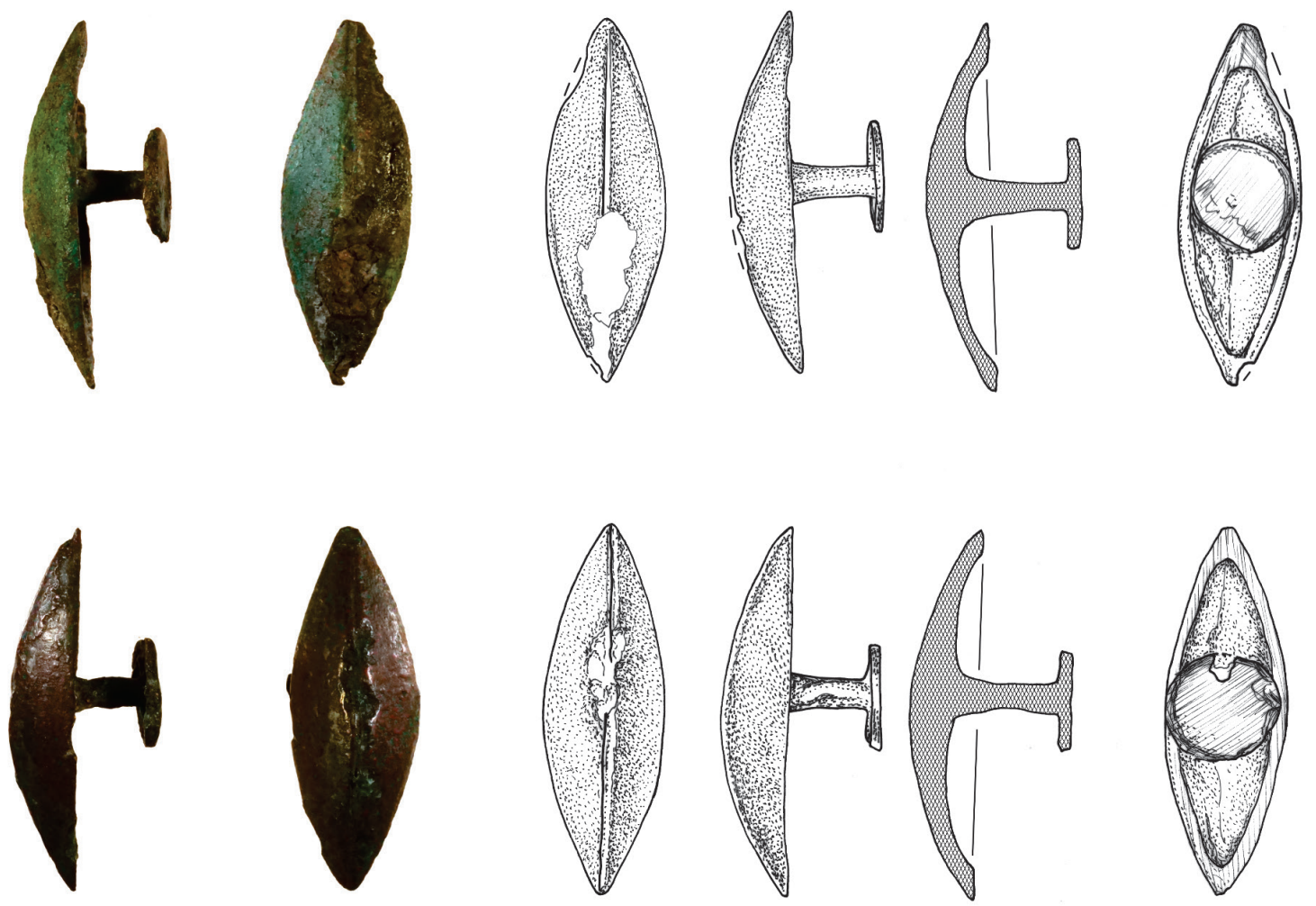

3.
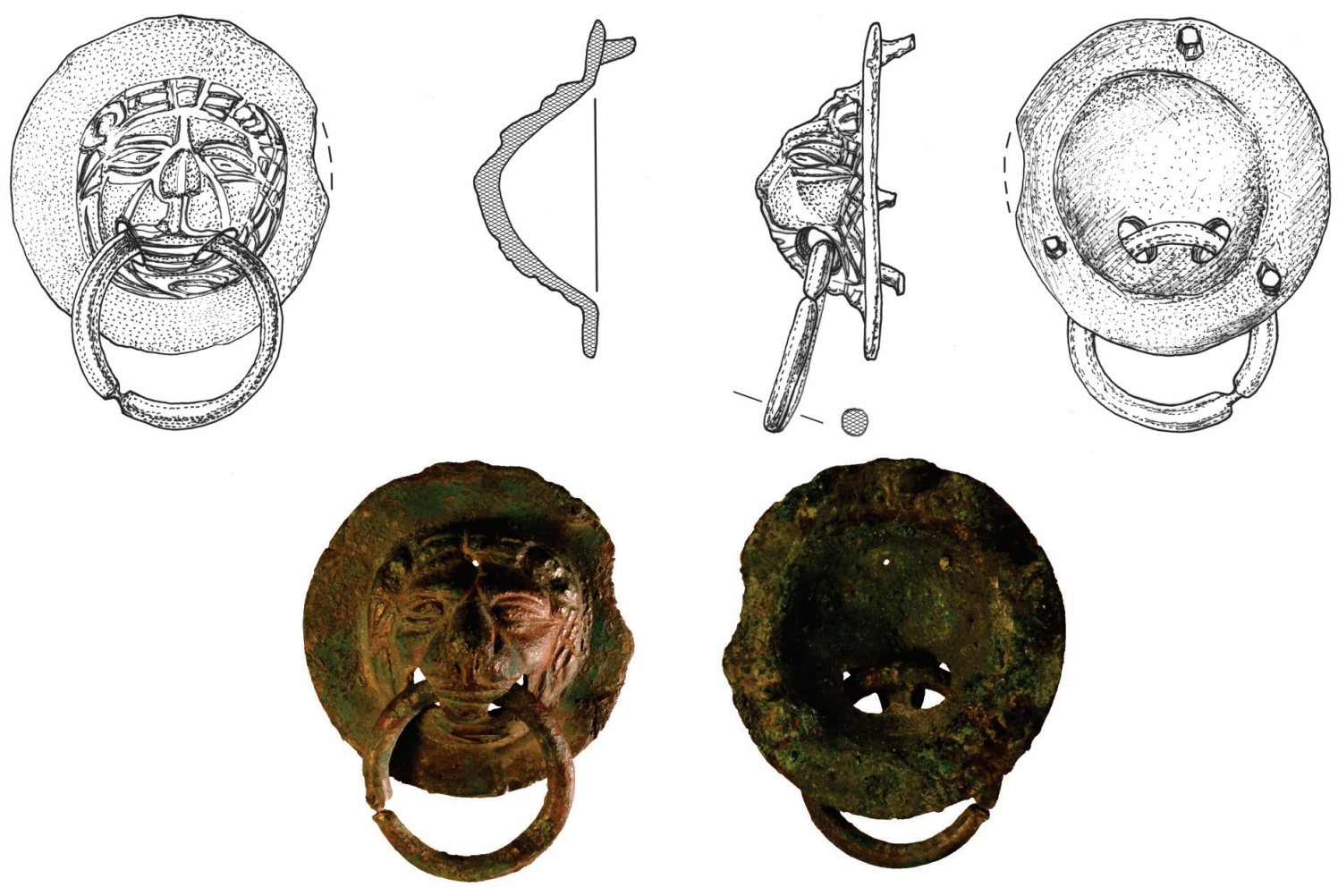

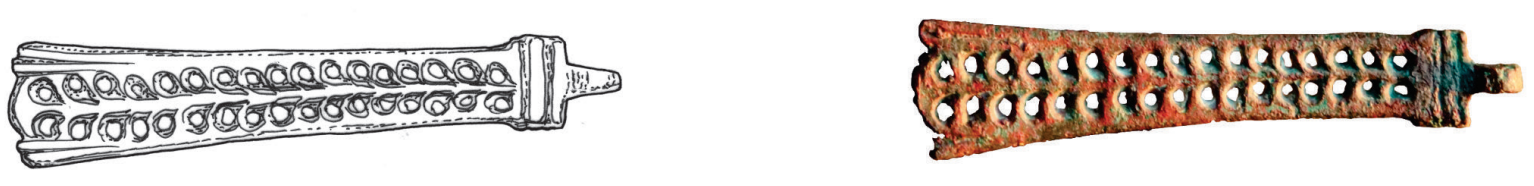

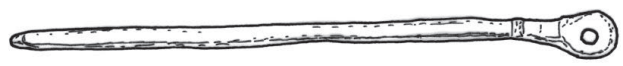



凅曾
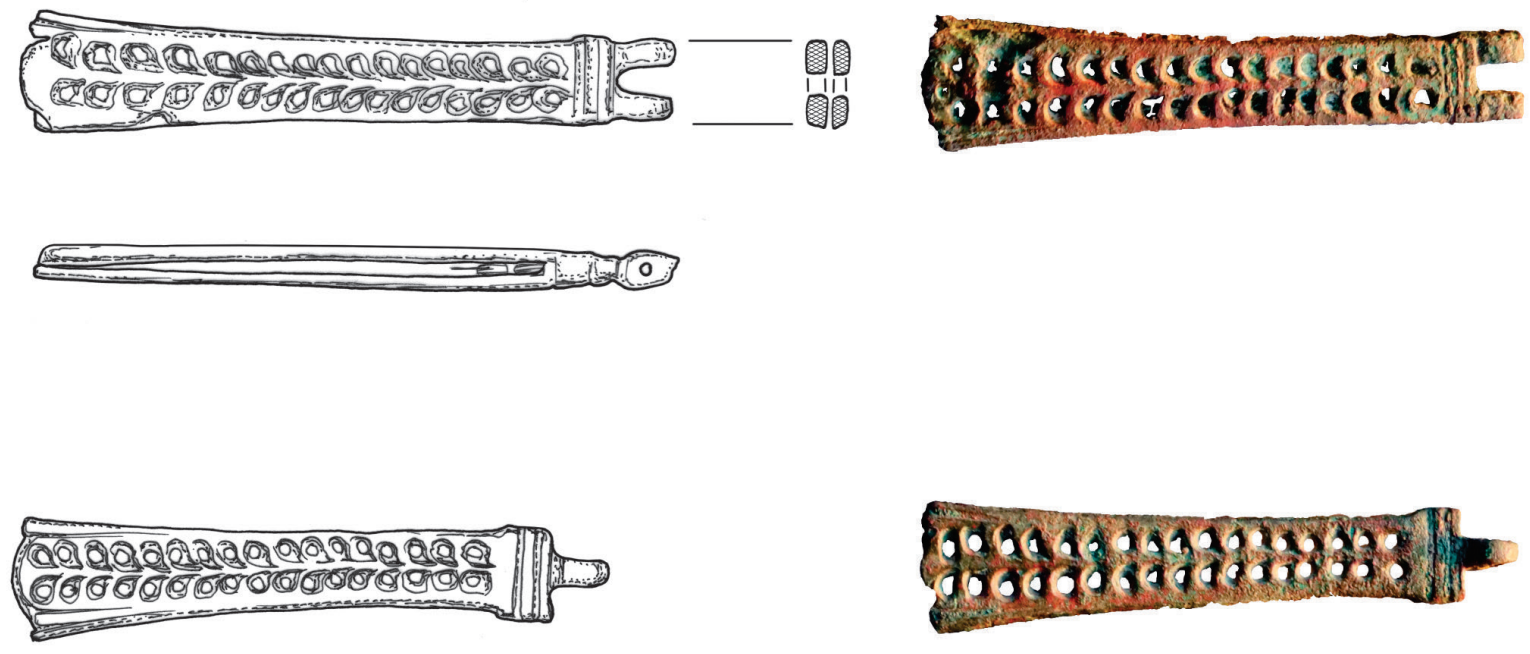

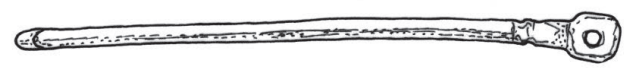
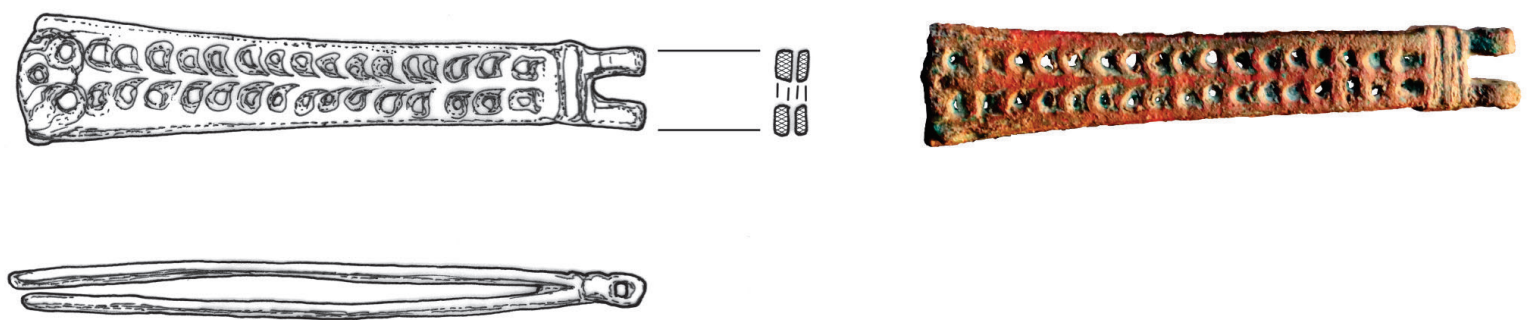

Pl. 3 . 
